\title{
ERGONOMIC WORK ANALYSIS APPLICATION IN A SMALL SHOE BUSINESS
}

\author{
Aline Marian Callegaro \\ Federal University of Rio Grande do Sul, Brazil \\ E-mail: nimacall@gmail.com
}

Henrique Simonetti Federal University of Rio Grande do Sul, Brazil E-mail: henrique_simonetti@yahoo.com.br

Fernando Gonçalves Amaral Federal University of Rio Grande do Sul, Brazil E-mail: amaral@producao.ufrgs.br

Carlos Fernando Jung Federal University of Rio Grande do Sul, Brazil E-mail: carlosfernandojung@gmail.com

Carla Schwengber ten Caten Federal University of Rio Grande do Sul, Brazil E-mail: tencaten@producao.ufrgs.br

Submission: 30/04/2013 Accept: 10/08/2013

\section{ABSTRACT}

This paper aims to present the results after conducting an Ergonomic Work Analysis (EWA) in a small shoe business located in Porto Alegre. The ergonomic intervention performed based on Guérin et al. (2001) aimed to analyze the process organization and the layout of the shoemaker workstations to provide improvements to these areas. The starting point was the need of the small shoe business owner to hire one more shoemaker without increasing the company physical space. The EWA was used focusing on the work organization, how the flow of information ran from the entry of an order to the final stage of the product repairing. The diagnosis showed the company main problems were related to the shop assistant dependences on shoemakers to provide budget information and delivery time to customers and the layout organization. Among the results, a temporal analysis of two 
DOI: 10.14807/ijmp.v4i2.84

company recurrent tasks was performed in order to ascertain possible losses related to the displacement and the search for materials. A new layout scheme was also proposed, aiming the organization of work stations, making easier the stock, tools and equipment removals, providing a free space to hirenew shoemakers within the current company boundaries.

Keywords: ergonomic application, Ergonomic Work Analysis (EWA); work organization; layout organization; shoe business

\section{INTRODUCTION}

Ergonomics is drawing attention of many productive sectors because its application is a way to raise overall productivity and worker satisfaction. These aids conquering better quality on the final product and lowering both error index and occupational accidents (MOURA, 2001).

A great advantage of the ergonomic approach is the combination of the current situation and the functional analysis for making improvements. A concept layout with process and task demands can be rethinking when the analysis includes processes (REMIJN, 2006).

Pohjonen et al. (1998) explains that the Ergonomic Work Analysis (EWA) can have good results related to the workers and, consequently, to the whole business. The EWA is a great method to develop the work content and to reduce the load on heavy demand tasks. The EWA also helps workers learn how to use their own abilities and needs to adjust the work frequency, not to mention it raises their selfconfidence and interest on ergonomics itself.

In view of the current situation of a small shoe business that needs microenterprise organization and layout improvements, and considering the great diversity of the EWA positive effects, the comfort and raise of productivity are the most current on literature (VINK et al., 2006); a research question was identified: How can the EWA help this small shoe business located in Porto Alegre downtown to improve their organization and layout?

Based on this relevant question to Industrial Engineering area, specifically to the Ergonomics research area, the paper aims to present the results of an EWA of a small shoe business located in Porto Alegre downtown (Rio Grande do Sul, Brazil), emphasizing the process organization and the layout of the shoemaker work stations 
INDEPENDENT JOURNAL OF MANAGEMENT \& PRODUCTION (IJM\&P)

http://www.ijmp.jor.br

V. 4, n. 2, July - September 2013.

ISSN: 2236-269X

DOI: 10.14807/ijmp.v4i2.84

to provide improvements to these areas and to the company. The article structure follows as: the second session presents the literature review, the third session contains the study methodology, the fourth session describes the results and the fifth session presents the study conclusions.

\section{LITERATURE REVIEW}

The work has positive aspects for people's life when it is satisfactory and produces good results. By the other hand, the work cannot produce positive effects when it becomes unhealthy and painful, performed in inadequate conditions as physical, emotional, organizational and environmental difficult conditions. The activity aspects, as well the environment situations need to be adequate to the worker and their activities, being motivating, avoiding physical discomforts, and improving the working quality plus the worker life quality (ROCHA; SIMONELLI, 2012).

In a most recent perception, the work is organized by managers and workers, based in part on the worker perceptions, their abilities and task characteristics (MESSING et al., 1998). Any work activity is part of a supply chain, in which every element is both a supplier and a costumer to the other elements (WILSON, 2000). Interactions happen in a wide net in this system and they are the true focus of the ergonomics (PARSONS, 2000).

According to International Ergonomics Association (2000) Ergonomics studies interactions among humans and other elements of a system. The ergonomist professional applies theoretical principles, data and methods to design in order to optimize human wellbeing and overall system performance. According to Carayon and Smith (2000) the concept of work organization and layout are directly related to ergonomics.

New approaches about work organizations have appeared in search of a higher industrial competitiveness, appreciating the human being and promoting its development, improving the performance on work tasks (MOURA, 2001). Carayon and Smith (2000) propose the Equilibrium Theory emphasizes a systemic approach where every element of the work system must be considered in order to achieve gains related to performance, safety and health of workers. The following lines have a brief description of each element of the work system proposed by this theory. 
INDEPENDENT JOURNAL OF MANAGEMENT \& PRODUCTION (IJM\&P)

http://www.ijmp.jor.br

V. 4, n. 2, July - September 2013.

ISSN: 2236-269X

DOI: 10.14807/ijmp.v4i2.84

- Ambient: special attention to aspects related to the physical characteristics as stressors, including noise level, luminosity, temperature, air quality and layout.

- Task: many of the psychosocial factors fall inside of this aspect as the work demand, the activity rhythm, cognitive demands, and the content of work, where the monotony or challenge levels are evaluated.

- Technology: the lack of adequate abilities to handle current technologies, and the fear of losing the job by replacement due to automation, leads to lack of motivation, stress and diminished performance. On the other hand, when new technologies are correctly applied, abilities and the work content can be improved, leading to better motivation, better performance and stress reduction.

- Organizational factors: the organizational contexts in which tasks are performed often have considerations that relate to motivation, stress and overall work performance. The way that workers are introduced to changes and organizational support that they receive - such as training and acclimation time - have strict relation to stress and performance, and to the possibility of getting better and being promoted.

- Individual: some personal worker characteristics can affect how they are going to interact with other system elements. They are included, but not limited to, the personality, physical health, anthropometry, skills, competence and previous experiences.

Reinforcing the importance of new approaches to the analysis of work organization, Battini et al. (2011) suggest that at least two types of variables must be studied. They include the technological variables, all variables related to product characteristics, factoring processes, industrial markets and the available plant space; as well ambient variables, which are all those related to work force, physical and mental safety, also considering psychosocial factors.

Vink et al. (2006) indicate the need of knowing some factors those must be considered in order to apply a successful ergonomics like: promoting the direct worker participation; organizing a support management; maintaining a good inventory; using a step-by-step approach; promoting the creation of a leading group with responsibilities; evaluating the effects, including the negative ones on an early 
INDEPENDENT JOURNAL OF MANAGEMENT \& PRODUCTION (IJM\&P)

http://www.ijmp.jor.br

V. 4, n. 2, July - September 2013.

ISSN: 2236-269X

DOI: 10.14807/ijmp.v4i2.84

stage; focusing beyond health questions; describing the cost-benefit relation in monetary terms and quantitative measures.

First and second factors are about the group participation and stakeholders (including managers, engineers, ergonomists and workers), and they are an essential topic for the project success. The next four items concern with the approach and the process, aiming to evaluate early its possibility to apply the ergonomic intervention and create a support group to lead the study. The last two focus on the content and the objective, promoting a way to present to final user the results of the health, comfort and productivity.

Smith and Carayon (1995) drag attention about the revolution of technology in relation to the work that caused a huge change on how work is managed and organized. Starting from this integration emerges the work and layout organization need to attend real worker needs both on macro and micro ergonomic level. Wahlström (2005) adds that interventions which include layout and task technique optimization reduce the physical load. As consequence, the worker performance improvement and the work related disease reduction can be observed.

According Rocha and Simonelli (2012) the EWA method considers the different employees and employers' point of view about the work process to confront their different perceptions and look for effective solutions to their demands. Thus, the ergonomist is able to intervene effective and favorably to workers and employers using the EWA method.

\section{METHODOLOGY}

This research is an exploratory study to survey the problem with a qualiquantitative approach. The study aims to explore the research problem and analyze the collected data quali-quantitatively to propose solutions to the research question.

Recommendations of Guérin et al. (2001) were used in this research. The EWA method allows the production process characterization by means of open and systematic observations and interviews. These tools contribute to the improvement of proposed working conditions, while taking into account the objectives of maintaining the workers' health and the range of productivity expected by shoe business owners.

The methodology is divided in three steps: (i) data collection; (ii) data analysis; and (iii) improvements. 
INDEPENDENT JOURNAL OF MANAGEMENT \& PRODUCTION (IJM\&P)

http://www.ijmp.jor.br

V. 4, n. 2, July - September 2013.

ISSN: 2236-269X

DOI: 10.14807/ijmp.v4i2.84

\subsection{Data collection}

The data collection was done during two visits to the microenterprise. Free and focused observations, interviews and photographic records were used to collect the data. The observations according to Moura (2001) are important to the EWA and allow the comprehension of the fabrication process by the man as well the device and tool use in the process.

Free observations, and open interviews with the employees and two owners were done during the first visit to the shoe business, in order to familiarize with the business, service system, organizational logic and general problems. Authorized photographic resources were used to register the layout.

A primary diagnosis has been done subsequently to the first visitation. This diagnosis guided the focused observations and the elaboration of the semi-structured research instrument comprised by open questions used in the second visit to the shoe business.

The second visit to the microenterprise was focused on the organizational process and layout, main identified problems in the first diagnosis. Two work cycles of a shoemaker were registered using a digital chronometer. Semi-opened interviews with a semi-structured research instrument comprised by open questions were done with workers and the shoe business owners to understand their needs for future comparisons to the ergonomic analysis made by the researchers. Interviews with the employees focused their (i) expectative about the ergonomic analysis of the work organization and layout; (ii) their main goals; (iii) their point of view about the tasks they do; and (iv) possible changes should be done in the microenterprise to improve their work quality of life. linterviews with the owners focused their (i) expectative about the ergonomic analysis of the work organization and layout; (ii) their main goals; (iii) their point of view about their own microenterprise; and (iv) possible changes they could do in the microenterprise to attend their goals.

\subsection{Data analysis}

The collected data on both free and focused observations, opened and semiopened interviews, as well other employees and owner verbalizations were registered on a field notebook. The field notebook registered content was analyzed using a content analysis (BARDIN, 2011), along with photographs, by quantifications, 
INDEPENDENT JOURNAL OF MANAGEMENT \& PRODUCTION (IJM\&P)

http://www.ijmp.jor.br

V. 4, n. 2, July - September 2013.

ISSN: 2236-269X

DOI: 10.14807/ijmp.v4i2.84

comparisons and inferences. The analysis was grouped on big categories related to the (i) demand characterization and process demand, (ii) primary diagnosis, (iii) process organization analysis, (iv) layout analysis, and (v) task temporal analysis. The task analysis corresponds to the real work executed by the employees (MOURA, 2001).

\subsection{Proposed Improvement}

After the data analysis, a general diagnosis was formulated, containing improvement propositions as shown in the result session.

\section{RESULTS}

This section presents the outcomes of each analysis category (i) demand characterization and process demand, (ii) primary diagnosis, (iii) process organization analysis, (iv) layout analysis, ( $v$ ) task temporal analysis; and (vi) general diagnosis and proposals for improvements.

\subsection{Demand Characterization and Process Demand}

The microenterprise studied in this research is a shoe business from the service sector. The microenterprise control is based on family. Three shoemakers, two clerks and two owners are part of the human resources. The employees' ages are between 20 and 50 years old. One of the shoemakers has 24 years of company work, the second one is working there for four years and the others started working a few months ago. The company has other clerk in training for the shoemaker position. Owners intend to organize the environment to place a workstation for the clerk in training and a new shoemaker.

There is no division of work among shoemakers, but there is division between shoemakers and clerks. Shoemakers provide support for clerks on customer service time when the demand is higher, as the winter time, for example.

The process demand involves the repairing around two hundred pairs of shoes per week. Each employee provides around twenty pairs per day. There are no predefined goals, but shoemakers must comply with deadlines for product deliveries to customers. 
INDEPENDENT JOURNAL OF MANAGEMENT \& PRODUCTION (IJM\&P)

http://www.ijmp.jor.br

V. 4, n. 2, July - September 2013.

ISSN: 2236-269X

DOI: 10.14807/ijmp.v4i2.84

Employees work eight hours daily. Their work schedules are from Monday to Friday, from nine a.m. to seven p.m. They have one break hour during this period. According to interviews, employees work on Saturdays when deliveries tend to delay.

Each shoemaker accomplishes the full repairing of shoe pairs; the repairing kind differs one from another. A complete cycle of work broadly includes two steps: (i) part removal from damaged shoes; (ii) repairing activities those include cutting, gluing, drilling, sewing, polishing, fixing parties and painting.

\subsection{Primary Diagnosis}

According to free observations, interviews, business owner's goals and workers' point of views, the main sector problems are related to the process organization and the environment layout, where workstations are placed.

The employees' point of views show the ventilation, lighting, the bench organization, as well workstations and shelves could also be improved. The tasks distribution between clerk and shoemaker should also be redefined.

The main process organization related problem focuses on the interdependence of customer service employees to those shoemakers. That means clerks rely on information from shoemakers to provide budget and estimated delivery date of products for repairing. Shoemakers depend of provided requests by the clerk to perform the proper repairing.

\subsection{Process Organization Analysis}

The process organization includes a flow of tasks that is performed for the shoes repairing provision (Figure 1). This organization involves the repairing order, clerk and shoemaker communication; repairing type determination, the budget and delivery date; the service order fulfillment; repairing shoes placement in the delivery day box (to organize the demand according the week day to deliver those to costumers); the repairing itself, the repaired shoes placement on the shelf, and the product delivery to the customer.

The main problem diagnosed in the process organization focuses on communication between clerks and shoemakers. Clerks move from the service desk to the workstation to request information about the repairing type, budget and delivery date definition. The delivery date is predefined in the work shift beginning. 
INDEPENDENT JOURNAL OF MANAGEMENT \& PRODUCTION (IJM\&P)

http://www.ijmp.jor.br

V. 4, n. 2, July - September 2013.

ISSN: 2236-269X

DOI: 10.14807/ijmp.v4i2.84

When customers request a flexible date, different of that predetermined; clerks require the date definition to shoemakers.

The difficulty is related to the shoemakers' work cycle interruption for providing information to the clerks. This determines a dependency relationship that is constantly being modified; shoemakers' work time should be optimized in this case.

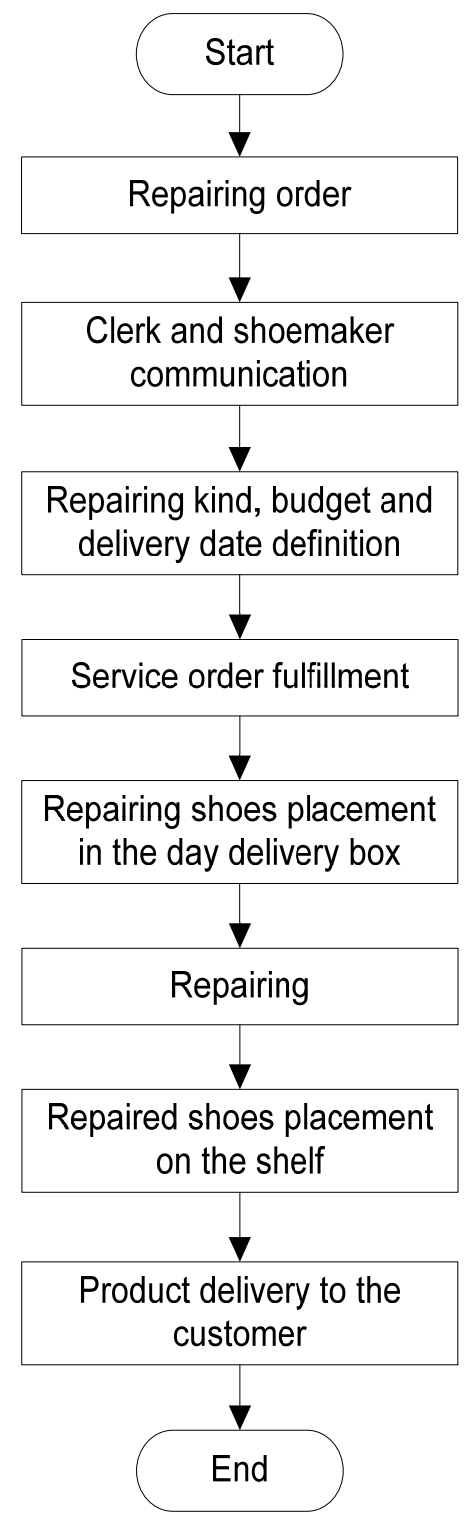

Figure 1: flowchart of task process.

\subsection{Layout Analysis}

The layout has problems related to the disorder and physical space (Figure 2). Materials are arranged in pots positioned on the shelf between the two workstations. 
INDEPENDENT JOURNAL OF MANAGEMENT \& PRODUCTION (IJM\&P)

http://www.ijmp.jor.br

v. 4, n. 2, July - September 2013.

ISSN: 2236-269X

DOI: 10.14807/ijmp.v4i2.84
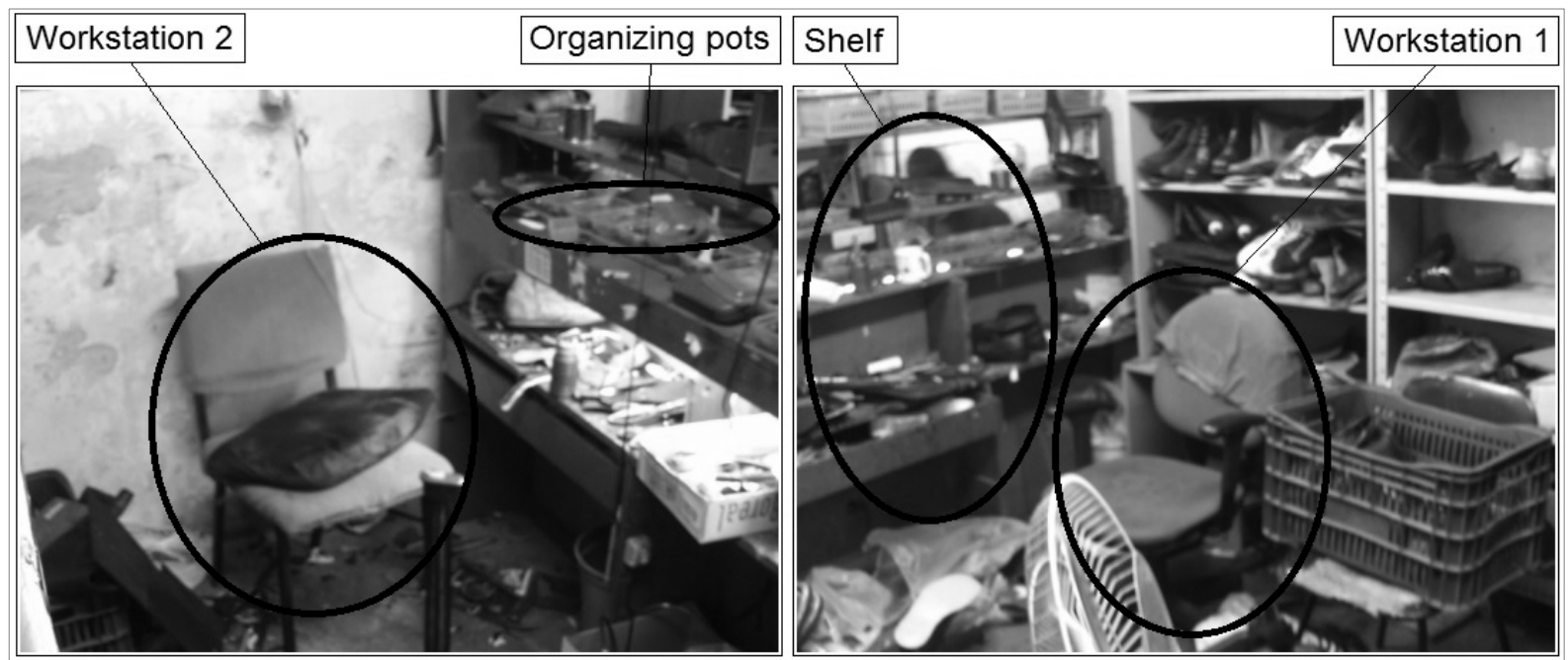

Figure 2: workstations and the shelf with materials and organizing pots.

The sanding machine used in all repairs is located in a room close by the workstations (Figure 3. A). Thus, shoemakers need to move from your workstations to go to the second room for each repairing. The painting station is also in a different room (Figure 3-B). This station is used by both shoemakers on specific repairing.
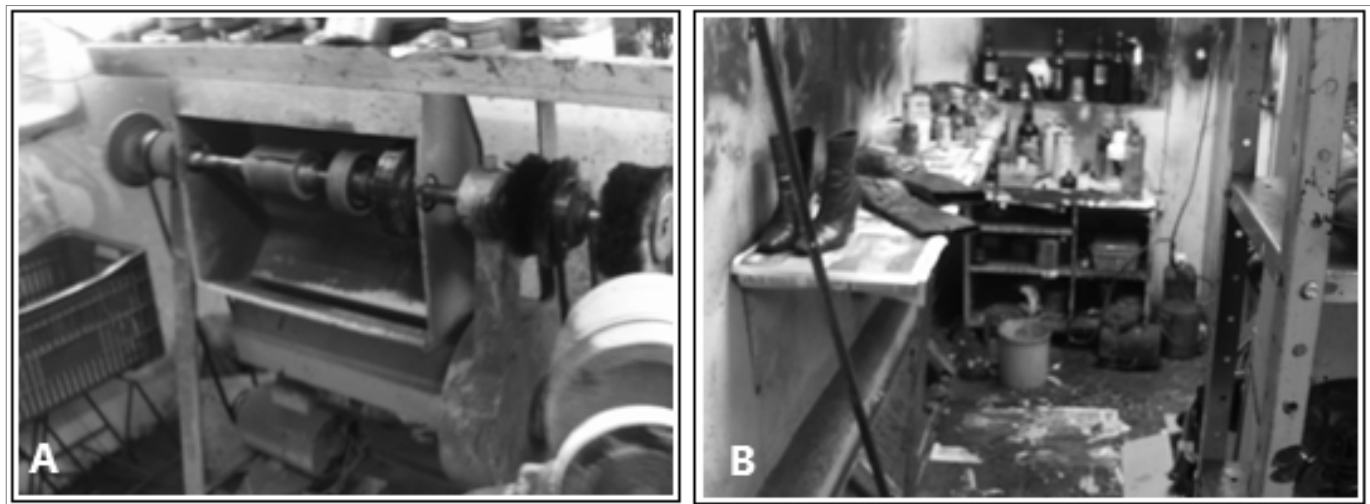

Figure 3: A - sanding machine station; B - painting station.

This analysis allows the development of a microenterprise layout scheme to understand better the environment as shown in Figure 4. The Desk 1 and Desk 2 in Figure 4 correspond to Workstation 1 and Workstation 2 illustrated in Figure 2, they belong to the primary place. This place layout is the subject of this ergonomic analysis study, where owners want to add other two workstations (one for the shoemaker in training and another for a new shoemaker). 
INDEPENDENT JOURNAL OF MANAGEMENT \& PRODUCTION (IJM\&P)

http://www.ijmp.jor.br

V. 4, n. 2, July - September 2013.

ISSN: 2236-269X

DOI: 10.14807/ijmp.v4i2.84

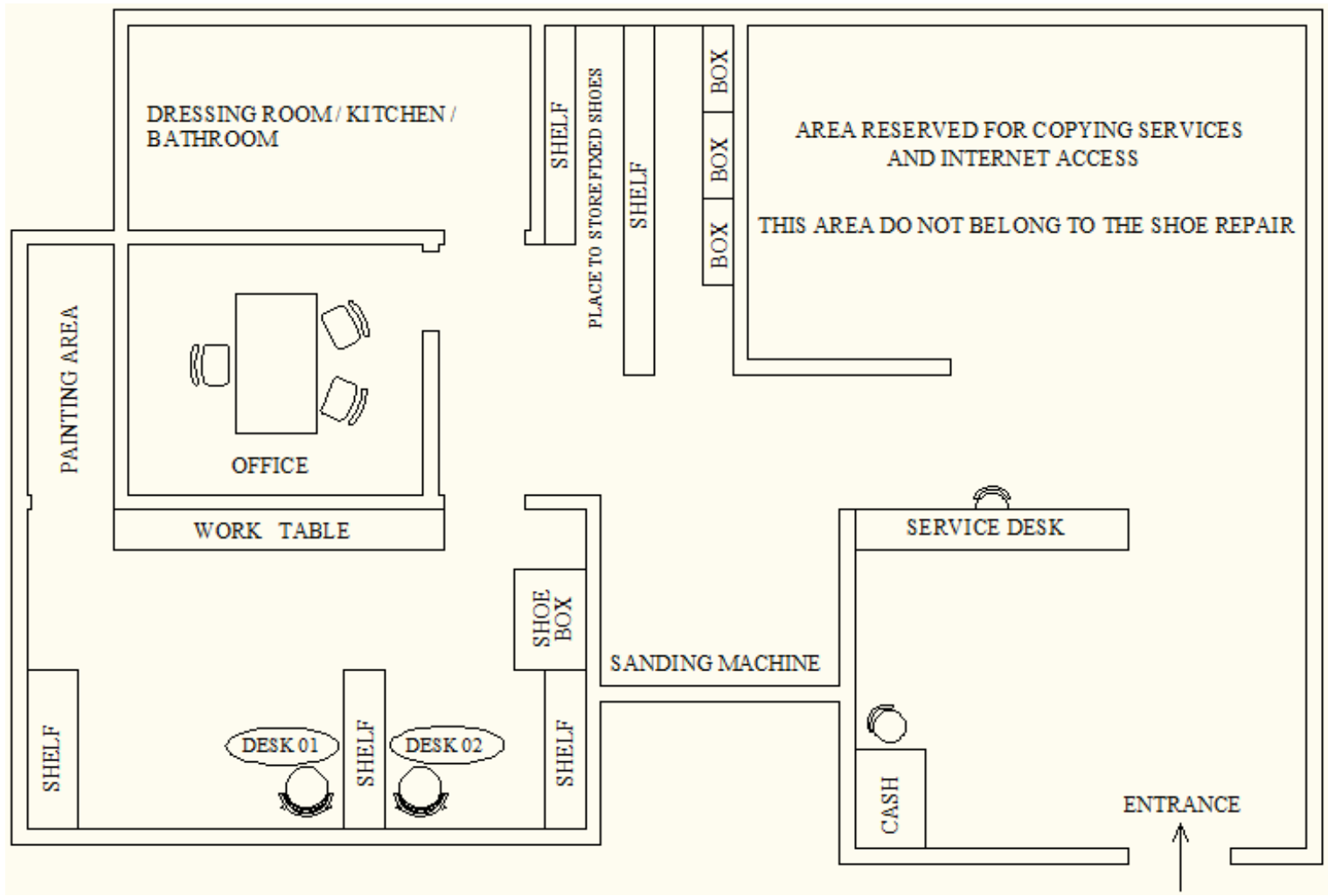

Figure 4: scheme of the microenterprise layout.

\subsection{Task Temporal Analysis}

The work cycles of two different repairing done by the most antique shoemaker were timed during the second researchers visit in order to organize the shoemakers' workplace layout. The temporal analysis of these tasks, as well observations and interviews helped the general diagnosis and proposals for improvements. The main goal of this assessment is to organize the tools used by the employees in a better way, optimizing the task execution time, reducing displacements to catch these tools and losses due to the layout organization.

The execution total time of the high heels repairing task of the pair of shoes was divided into (i) task time, (ii) displacement time and (iii) loss time (Figure 5). The task time refers to the time used to execute different activities comprise the task; the displacement time refers to the stand-up moment from the workstation to move until the sanding machine location. The losses are indicative of the search time, catching tools and necessary materials for the material repairing and their preparation to be used in the repairing work.

The losses of this first task correspond to $7 \%$ of the execution total time of the high heels repairing, which equals 41 seconds of the total time (10 minutes and 4 
INDEPENDENT JOURNAL OF MANAGEMENT \& PRODUCTION (IJM\&P)

http://www.ijmp.jor.br

V. 4, n. 2, July - September 2013.

ISSN: 2236-269X

DOI: 10.14807/ijmp.v4i2.84

seconds). This loss specifically refers to the searching time for the hammer and material used by the shoemaker to do the work.

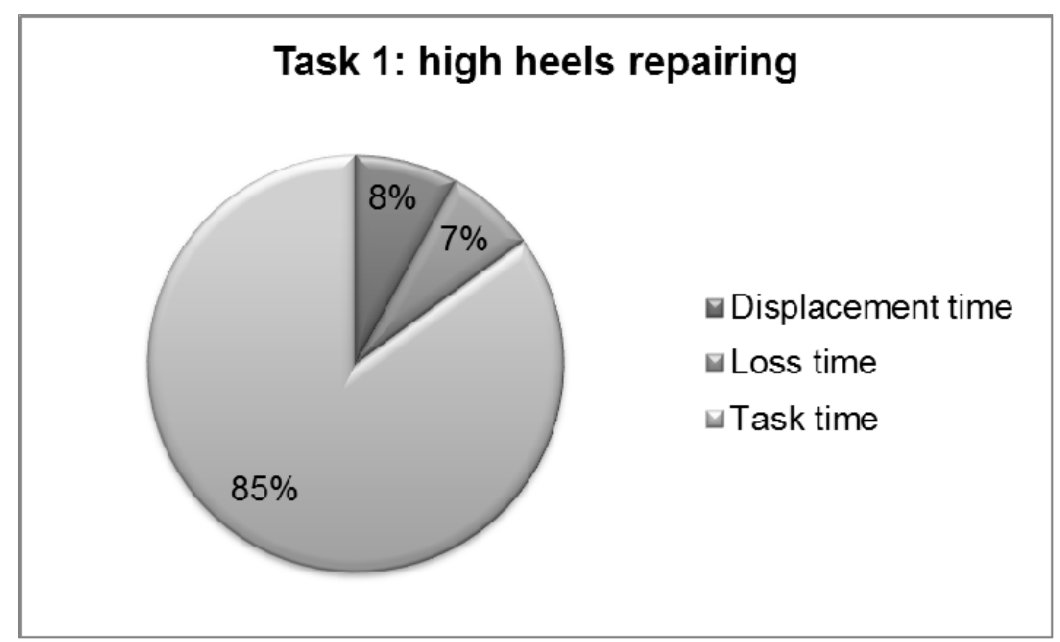

Figure 5: graphic of temporal distribution of the high heel repairing task.

The displacement time corresponds to $8 \%$ of total time of the task execution (46 seconds) includes two displacements: the first one correspond to the displacement from the workstation to the sanding machine localized in the room beside workstations, and the second one correspond to the displacement from sanding machine station to the shelf to store the repaired product for delivery.

The work cycle of the second analyzed task (Figure 6) refers to the tip reinforcement and shoes high heels repairing. The execution total time was 22 minutes and 3 seconds. The percentage refers to the loss (6\% - 1 minute and 22 seconds) and displacements (4\% - 50 seconds) are lower than first analyzed work cycle. The losses in this second case include the search for material, actions to catch and prepare the materials, and the failure to perform.

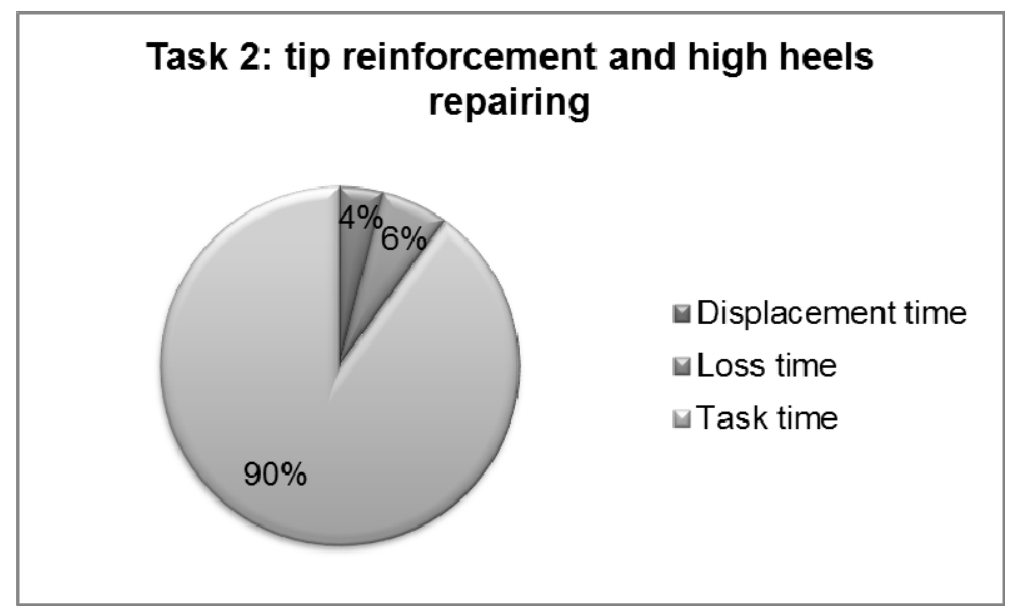

Figure 6: graphic of temporal distribution of the reinforcement and heel tip repair task. 
INDEPENDENT JOURNAL OF MANAGEMENT \& PRODUCTION (IJM\&P)

http://www.ijmp.jor.br

V. 4, n. 2, July - September 2013.

ISSN: 2236-269X

DOI: 10.14807/ijmp.v4i2.84

\subsection{General Diagnostic and Proposals for Improvements}

Based on these analyses, it can be inferred that the more specific findings confirm the primary diagnosis. That is, the general diagnostic clarifies that main failures are in the process organization, the shoemaker-clerk interdependence specifically and the layout organization. Both malfunctions affect the shoemakers' productivity. Thus, proposals for improvements are based on the general diagnosis, the study of workers interaction with objects they use in their tasks, along with the work environment.

The first proposal is a pre-determination by shoemakers of a specific number for exception services relating to the delivery date, it means the possible maximum anticipation number of services for those customers request emergency services. This definition must be stated before the task time in order to solve the problem related to the interdependence shoemaker-clerk. The second proposal is a table with the different repairing types and their specific prices, which should be available to clerks to avoid interruption of the shoemaker work. Thus, shoemakers will only be interrupted in extremely necessary cases.

Based on the layout and task analyses, a layout organization that provides better arrangement of tools and materials needed for repairs can be proposed. Each operator should have their tools in order to reduce the search time and minimize losses. Common use materials must have pre-defined places for both shoemakers to find them as quickly as possible, minimizing the search time.

As displacements are due to the need of using the sanding machine and, according to interviews with the owners and employees, no possibilities to put it close by to the workstations. The suggestion is the shoemaker performs task steps do not require the sanding machine use in more than one pair of shoes. When the shoemaker goes to the sanding machine station for the station task steps, more than one pair of shoes will be performed, reducing the total number of daily displacements to the half.

Taking all these aspects into consideration, compared with employees and owners' goals, a scheme for layout organization of the workstation environments is proposed in the Figure 7. 
INDEPENDENT JOURNAL OF MANAGEMENT \& PRODUCTION (IJM\&P)

http://www.ijmp.jor.br

V. 4, n. 2, July - September 2013.

ISSN: 2236-269X

DOI: 10.14807/ijmp.v4i2.84

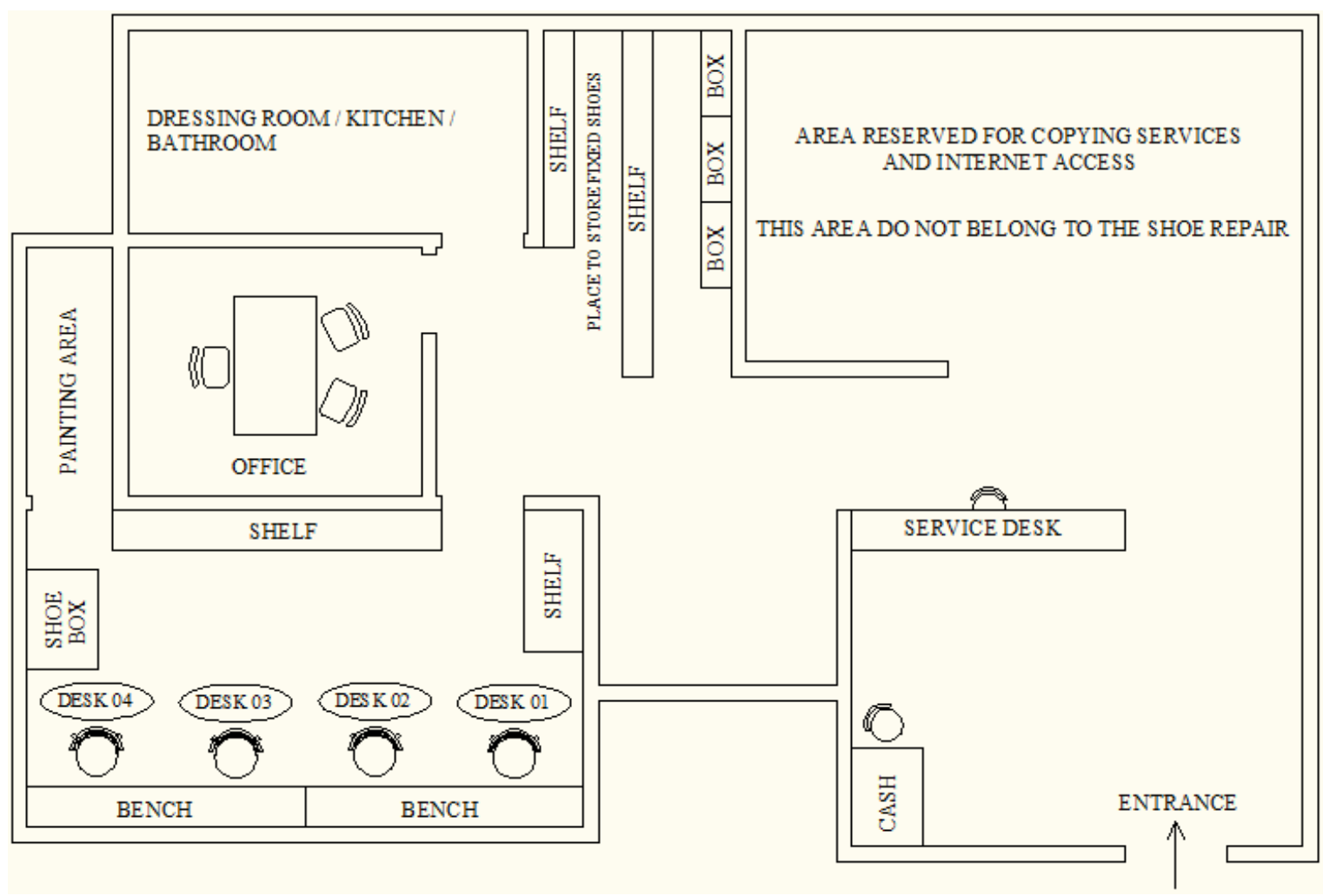

Figure 7: proposed organization to the workstations environment.

According to this proposed scheme (Figure 7), owners need to invest in a further bench, replacing the counter current by the shelf which is originally placed along of the workstation 1. The shelf shown in Figure 2 is positioned between the Workstation 1 and 2 are replaced by other bench. The new bench is placed together to that existing one, because this second bench on the wall would leave the original position and it would pair with the new bench.

Material organizing pots should be placed on these benches to be available to all shoemakers. The shelf constituent material, shown in Figure 2, could be used for the production of shelves above the bench. Thus, each worker could organize their tools and materials. Emphasizing that each shoemaker should have their own tools and need materials on the operation range of repairing to avoid frequent displacements and search for materials.

The box for the demand organization that is positioned within the shoemakers' working place would be repositioned on the opposite wall to its original position. It is important to highlight this new proposal for organizing the layout requires the lighting analysis to provide the shoemaker visual comforts on their workstations. 
INDEPENDENT JOURNAL OF MANAGEMENT \& PRODUCTION (IJM\&P)

http://www.ijmp.jor.br

V. 4, n. 2, July - September 2013.

ISSN: $2236-269 X$

DOI: 10.14807/ijmp.v4i2.84

\section{CONCLUSIONS}

The ergonomic analysis is essential to adapt the workplace to the main subject, who is the employee. Therefore this study conducted an ergonomic analysis of a small shoe business (Porto Alegre downtown, Rio Grande do Sul, Brazil) process and layout organization, proposing improvements to those.

According to the research, the main failures observed found in the organization process, because the clerk needs to communicate with shoemakers requesting information about the repairing type, delivery time and budget of the service to help themselves frequently. Layout problems were also identified, especially the need of organizing the workplace and workstations for current employees, as well as creating two other workstations for the new employees.

It was proposed to the shoe business a better organization of communication between shoemakers out of opening hours and making a handy table with the different repairing and prices. New furniture and workstation arrangements were suggested to reorganize the layout, such as replacing a shelf for a new bench, organizing shoemaker's tools and other available materials. These suggestions would assist workers and reduce the required time for each repairing with consequent reduction of losses.

This study can also be continued with a focus on official proposals to reorganize the layout with the relevant furniture provisions, as well as tools and material distributions. Other ergonomic analysis with differentiated approaches aiming noise, lighting and ventilation analysis can be done. Problems like these were also found in this small shoe business and they are being resolved by the owners, but that could be supported by an ergonomist.

\section{REFERENCES}

INTERNATIONAL ERGONOMICS ASSOCIATION (2000). Defination of ergonomics. Available: http://www.iea.cc/. Access: 08/19/2-13.

BARDIN, L. (2011) Análise de conteúdo. São Paulo: Edições 70.

BATTINI, D. et al. (2011) New methodological framework to improve productivity and ergonomics in assembly system design. International Journal of Industrial Ergonomics, v. 41, n. 1, p. 30-41.

CARAYON, P.; SMITH, M. J. (2000) Work organization and ergonomics. Applied Ergonomics, v. 31, n. 6, p. 649-662. 
INDEPENDENT JOURNAL OF MANAGEMENT \& PRODUCTION (IJM\&P)

http://www.ijmp.jor.br

v. 4, n. 2, July - September 2013.

ISSN: $2236-269 X$

DOI: 10.14807/ijmp.v4i2.84

GUERIN, F. et al. (2001). Compreender o trabalho para transformá-lo: a prática de ergonomia. São Paulo: Edgard Blucher.

MESSING, K.; CHATIGNY, C.; COURVILLE, J. (1998) "Light" and "Heavy" work in the housekeeping service of a hospital. Applied Ergonomics, v. 29, n. 3, p. 451459.

MOURA, P. R. C. (2001) Rotação de postos de trabalho: uma abordagem ergonômica. Dissertation (Master in Engineering). Porto Alegre: UFRGS. Available: http://hdl.handle.net/10183/3239. Access: 04/30/2013.

PARSONS, K. C. (2000) Environmental ergonomics: a review of principles, methods and models. Applied Ergonomics, v. 31, n. 6, p. 581-594.

POHJONEN, T.; PUNAKALLIO A.; LOUHEVAARA, V. (1998) Participatory ergonomics for reducing load and strain in home care work. International Journal of Industrial Ergonomics, v. 21, n. 5, p. 345-352.

REMIJN, S. L. M. (2006) Integrating ergonomics into the architectural design processes: tools for user participation in hospital design. In: WORLD CONGRESS ON ERGONOMICS, 16, Maastricht, Proceedings... Maastricht: IEA, 2006.

ROCHA, L. F.; SIMONELLI, A. P. (2012) A utilização da análise ergonômica do trabalho como ferramenta do terapeuta ocupacional no estudo da atividade de trabalho de cabeleireiros. Cadernos de Terapia Ocupacional da UFSCar, v. 20, n. 3, p. 413-424.

SMITH, M. J.; CARAYON, P. (1995) New technology, automation, and work organization: Stress problems and improved technology implementation strategies. International Journal of Human Factors in Manufacturing, v. 5, n. 1, p. 99-116.

VINK, P.; KONINGSVELD, E. A. P.; MOLENBROEK, J. F. (2006) Positive outcomes of participatory ergonomics in terms of greater comfort and higher productivity.

Applied Ergonomics, v. 37, p. 537-546.

WAHLSTRÖM, J. (2005) Ergonomics, musculoskeletal disorders and computer work. Occupational Medicine, v. 55, n. 3, p. 168-176.

WILSON, J. R. (2000) Fundamentals of ergonomics in theory and practice. Applied Ergonomics, v. 31, n. 6, p. 557-567. 